\title{
Red pasta: What is the technological impact of the enrichment of beet ingredient in fresh pasta?
}

\author{
Josemar Gonçalves de Oliveira Filho ${ }^{1}$, Ailton Cesar Lemes ${ }^{2}$, Ricardo Pereira Cruz Filho ${ }^{3}$, Rafaiane Macedo \\ Guimarães, Kamylla Lina Oliveira ${ }^{3}$, Gabriela Silva Santana ${ }^{3}$, Eliane Dalva Godoy Danesi ${ }^{5}$, Mariana Buranelo \\ Egea $^{4^{*}}$
}

${ }^{1}$ School of Pharmaceutical Sciences, São Paulo State University (UNESP), Araraquara, Brazil; ${ }^{2}$ Department of Biochemical Engineering, School of Chemistry, Federal University of Rio de Janeiro (UFRJ), Rio de Janeiro, Brazil; ${ }^{3}$ Goiano Federal Institute, Morrinhos, Brazil; ${ }^{4}$ Goiano Federal Institute, Rio Verde, Brazil; ${ }^{5}$ Department of Food Engineering, State University of Ponta Grossa, Ponta Grossa, Brazil

*Corresponding author: Mariana Buranelo Egea, Goiano Federal Institute, Rio Verde, Rodovia Sul Goiana, Km 01, Rural Area, 75901-970, Rio Verde, Goiás, Brazil. E-mail: mariana.egea@ifgoiano.edu.br

Submitted: 23 November 2020; Accepted: 23 March 2021; Published: 27 April 2021

(c) 2021 Codon Publications

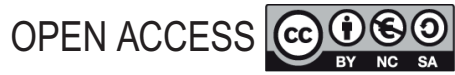

RESEARCH ARTICLE

\begin{abstract}
The objective of this study was to evaluate the partial replacement of wheat flour by beet flour (BF) in fresh pasta production, analyzing its chemical, technological, and sensorial characteristics. BF showed good water (4.2 g water/g flour) and oil absorption (2.2 g oil/g flour), water solubility (67.3\%), and emulsifying properties (30.0\%). The incorporation of $\mathrm{BF}$ in fresh pasta formulations improved the nutritional value of the pasta, increased the ash ( 1.65 to $2.16 \mathrm{~g} / 100 \mathrm{~g}$ ) and fiber contents ( 1.31 to $12.29 \mathrm{~g} / 100 \mathrm{~g}$ ) of the fresh pasta, and decreased the lipid contents ( $50.0 \%$ reduction), thereby causing changes in its cooking properties. The antioxidant capacity ( 0.5 to $4.76 \%)$ and the content of total phenolics (69.1 to $70.5 \mathrm{mg} / 100 \mathrm{~g})$ and betalains ( 0.04 to $0.16 \mathrm{mg} / 100 \mathrm{~g})$ also increased with the addition of $\mathrm{BF}$, improving the functional profile of the pasta. In the sensory profile, the pasta formulated with the highest concentrations of $\mathrm{BF}$ demonstrated the highest intensities for the sensory attributes among fresh pasta evaluated. In general, it was shown that BF represents a promising ingredient to produce new fresh pasta with functional characteristics.
\end{abstract}

Keywords: antioxidant activity; betalains; functional product

\section{Introduction}

Cereal-based foods are of paramount importance in human nutrition since they represent $30-70 \%$ of daily energy intake (Nishida et al., 2004). Pasta is a traditional, cereal-based food, which is very popular worldwide due to its convenience of preparation, nutritional quality, and palatability (Cappa and Alamprese, 2017; Littardi et al., 2020; Tazrart et al., 2019). Pasta is a product of pasting and mechanical kneading, where proteins and starch granules absorb water and lipids to form an emulsion. In kneading, the absence of bubbles is desired because it results in a more compact, resistant, and translucent product.
Triticum durum is commonly used as a raw material for the production of high-quality pasta, as it has characteristics that influence consumer satisfaction, such as culinary properties, color, and aroma (Lee et al., 2002). In Brazil, T. durum is not produced and for this reason, $85 \%$ of the pasta is produced with common wheat. Thus, adaptations are needed in the formulation of the doughs in order to improve their nutritional and technological quality (Chang and Martínez Flores, 2004).

Pasta can be fresh, dried, instant, and precooked, among others, but in all of these cases, it passes through rolling mills where rolling and cutting is carried out. Most of the fresh pasta consumed is characterized by the presence 
of gluten proteins and being a good source of carbohydrates with a low glycemic index (Fradinho et al., 2020; Giménez et al., 2013; Littardi et al., 2020; Sissons et al., 2007). Although fresh pasta is not seen as a nutritionally balanced food or with functional properties due to its low fiber, bioactive contents, and biological protein value, pasta has a high acceptability index and is a fast, versatile, and low-cost food. For this reason, pasta is a good vehicle for nutritional enrichment with the bioactive compound source and can become a functional food (De Santis et al., 2020; Fradinho et al., 2020; Kowalczewski et al., 2019).

Beet (Beta vulgaris L.) is a species belonging to the Chenopodiaceae family, rich in minerals, phenolic compounds (including phenolic acids and flavonoids), and betalains (Pandita et al., 2020). Betalains are important red water-soluble pigments in the human diet because they act as antioxidants, combating free radicals and protecting against some diseases related to oxidative stress (Vasconcellos et al., 2016). The production of flours/ ingredients from different plant sources is highly encouraged in nutritional enrichment to food development. In this sense, beet flour (BF) has been proposed as an interesting ingredient for the production of innovative and fortified product formulations such as muffins (Seo and Ko, 2014), bread (Lee and Ju, 2016), as well as biscuits (Joo and Kim, 2010) and cookies (Chauhan and Rajput, 2018; Clímaco et al., 2020; Sahni and Shere, 2016). As far as we know, the effect of BF incorporation on the technological properties of fresh pasta or, mainly, BF incorporation with the aim of increasing the concentration of functional components as a strategy to promote a more diverse and nutritious diet has not been studied. Thus, it is necessary to assess whether fresh pasta can be used as a vehicle to promote the functional components present in BF and with good sensory acceptability. Therefore, the objective of this study was to evaluate the partial replacement of wheat flour by BF in fresh pasta production, and evaluate its chemical, technological, and sensorial characteristics.

\section{Material and Methods}

\section{Materials and flour production}

The beets were collected, washed, and sanitized in sodium hypochlorite solution at $50 \mathrm{ppm}$, peeled, cut in a Philips Walita RI7762 processor (São Paulo, Brazil), and dried in a convective dryer (Ethik Technology/400$4 \mathrm{ND}$, Botucatu, Brazil) at $60^{\circ} \mathrm{C}$ for $12 \mathrm{~h}$. The dry product was ground and homogenized on a 20 mesh screen. The ingredients were obtained from the local market: wheat flour (Cristal Alimentos, Goiânia, Brazil), eggs (Ovos Jusidith, Leopoldo de Bulhões, Goiás, Brazil), and salt (Sal Cisne', São Paulo, Brazil).

\section{Fresh pasta production}

The processing of fresh pasta was as described by Lemes et al. (2012). Briefly, the standard formulation contained $100 \%$ wheat flour, $21.43 \%$ eggs, $0.7 \%$ salt, and $26.42 \%$ water. Wheat flour was replaced with BF in the percentages of 5, 10, and 15. The ingredients were homogenized, and the dough was manually laminated, cut into the "noodle" type, and stored for $24 \mathrm{~h}$ under refrigeration $\left(4^{\circ} \mathrm{C}\right)$ until analysis.

\section{Chemical characterization}

The contents of moisture, lipid (Bligh \& Dyer method), protein (conversion factor $=5.75$ ), ash, carbohydrate, and dietary fiber (K-TDFR-Megazyme enzyme kit) were determined according to official Methods (AOAC, 2007). To determine the energy value, the Atwater conversion factors were used based on the proximate composition of the sum of the contents of protein $\times 4$, lipid $\times 9$, and carbohydrate $\times 4$ (AOAC, 2000).

To determine the concentration of betalains in the samples of BF and fresh pasta, a sample $(0.2 \mathrm{~g})$ was diluted with distilled water $(5 \mathrm{~mL})$ and filtered with a vacuum pump with Whatman filter paper No. 1. The filtrate was read at $536 \mathrm{~nm}$ and was performed in triplicate. To quantify the betalain content in the samples, the calculation was used according to the Beer-Lambert-Bouguer Law modified by Tang et al. (2007). The content of total phenolic compounds (TPC) was determined according to the method proposed by Singleton and Rossi (1965), modified by Li et al. (2009). Antioxidant capacity was measured using the 2,20-azinobis-(3-ethyl-benzothiazoline-6-sulfonic acid (ABTS) method (Miller et al., 1993), modified by Rufino et al. (2010); 2,2-difenil-1picril-hidrazil (DPPH) (Brand-Williams et al., 1995); and the Ferric-reducing antioxidant power (FRAP) method (Benzie and Strain, 1999).

\section{Technological and functional properties of the beet ingredient and fresh pasta}

Water absorption index (WAI), water solubility (WS), and oil absorption capacity (OAC) were determined according to the method described by Okezie and Bello (1988). Foaming properties were evaluated according to the method proposed by Coffmann and Garciaj (1977), with modifications. Briefly, the BF $(1 \mathrm{~g})$ was mixed with distilled water $(50 \mathrm{~mL})$ with vigorous stirring for $5 \mathrm{~min}$, and subsequently transferred to a $100 \mathrm{~mL}$ beaker. The volumes were recorded before and after stirring. The foam capacity (FC) index was calculated as the percentage ratio of the increased volume, compared to the initial 
volume. Foam stability was determined at 30, 60, 90, and $120 \mathrm{~min}$ after formation.

Emulsifying capacity (EC) was evaluated according to Yasumatsu et al. (1972), with modifications. The sample $(1 \mathrm{~g})$ was mixed with distilled water $(10 \mathrm{~mL})$ and soy oil $(10 \mathrm{~mL})$. The mixture was stirred in a homogenizer (Q235 Quimis ', São Paulo, Brazil) for 1 min. After stirring, the emulsions were centrifuged (Novatecnica ${ }^{\circ} \mathrm{NT}$ 810, Piracicaba, Brazil) at $5000 \times g$ for $5 \mathrm{~min}$. EC was calculated by dividing the height of the emulsified layer by the total height and expressed as a percentage.

The gel-forming capacity was evaluated according to the method proposed by Coffmann and Garciaj (1977) using concentrations ranging from 2 to $20 \%$ of the sample and distilled water $(20 \mathrm{~mL})$. The mixtures were placed in a water bath at $90^{\circ} \mathrm{C}$ for $30 \mathrm{~min}$, cooled in running water for $20 \mathrm{~min}$, and placed in a refrigerator $\left(4^{\circ} \mathrm{C}\right)$ for $2 \mathrm{~h}$. Visual observation was performed to detect the presence of gel when inverting the tube.

Pasta was evaluated for cooking characteristics (66-50) (AACC, 2000). Cooking time was the time necessary to reach the point al dente using $20 \mathrm{~g}$ of pasta, $2 \mathrm{~g}$ of salt, and $200 \mathrm{~mL}$ of water. Water absorption was calculated based on an increase of the weight of $20 \mathrm{~g}$ of pasta after the cooking process and was expressed in percentage. Volume displacement was evaluated by water volume displacement of $20 \mathrm{~g}$ sample after the cooking process. Loss of solids was determined by drying at $105^{\circ} \mathrm{C}$ the water obtained after cooking of $20 \mathrm{~g}$ of fresh pasta. Water retention capacity was determined using $1 \mathrm{~g}$ of sample homogenized in $10 \mathrm{~mL}$ of water, subjected to heating in a water bath at $80^{\circ} \mathrm{C}$ for $45 \mathrm{~min}$, and centrifuged at $2000 \mathrm{rpm}$ for $20 \mathrm{~min}$. The results were expressed as a percentage of the increase of weight after water adsorption.

\section{Sensorial analysis: ranking descriptive analysis}

A selected and trained sensory panel, consisting of 12 judges, evaluated the four samples using Ranking Descriptive Analysis (RDA). The terms most frequently cited in the assessors' individual list were selected to compose the score sheet for the RDA panel according to the Kelly Network Method (1955) and are presented in Table 1. The assessors defined the attributes and suggested qualitative references based on the samples and other commercial products. Posteriorly, qualitative references were presented and checked by the panel. Finally, the samples were ordered in increasing intensity for each attribute. The repeatability, discrimination, and the homogeneity of judges' scores were checked by a two-way ANOVA after 6 sessions of $1 \mathrm{~h}$ each. In the final evaluation, all the fresh pasta formulations were presented simultaneously after cooking and the judge was asked to order in increasing order of intensity each of the previously defined attributes. RDA data were evaluated by Friedman's test (Newell and MacFarlane, 1987) to verify differences between samples for each attribute, considering four samples and the number of final judges (critical value: see table, $\mathrm{P} \leq 0.05$ ). The entire procedure was previously approved by the Research Ethics Committee of Instituto Federal Goiano (CAE 71848117.6.0000.0036).

Table 1. Attributes, definitions, and reference samples for attributes utilized in Ranking Descriptive Analysis (RDA) of fresh pasta.

\begin{tabular}{|c|c|c|}
\hline Attribute & Definition & Reference \\
\hline \multicolumn{3}{|l|}{ Appearance } \\
\hline Red color & $\begin{array}{l}\text { Intensity of color between white and } \\
\text { red }\end{array}$ & $\begin{array}{l}\text { WEAK: Santa Amália Speciali Tagliatelle }{ }^{\circledR} \text { noodles } \\
\text { INTENSE: colored screw pasta }\end{array}$ \\
\hline Homogeneous appearance & $\begin{array}{l}\text { Absence of lumps or particles visually } \\
\text { perceived }\end{array}$ & $\begin{array}{l}\text { WEAK: Renata }{ }^{\circledR} \text { noodles homemade-type pasta with hard whole eggs } \\
\text { INTENSE: Santa Amália Speciali Tagliatelle }{ }^{\circledR} \text { noodles }\end{array}$ \\
\hline \multicolumn{3}{|l|}{ Aroma } \\
\hline Egg aroma & Typical beaten egg aroma & $\begin{array}{l}\text { WEAK: beaten egg white in snow } \\
\text { INTENSE: beaten whole egg }\end{array}$ \\
\hline Beet aroma & Typical beet aroma & $\begin{array}{l}\text { WEAK: diluted (1:100) beet cooking water } \\
\text { INTENSE: cooked beets }\end{array}$ \\
\hline \multicolumn{3}{|l|}{ Flavor } \\
\hline Beet flavor & Typical beet flavor & $\begin{array}{l}\text { WEAK: diluted (1:100) beet cooking water } \\
\text { INTENSE: cooked beets }\end{array}$ \\
\hline Sweetness flavor & Sweet taste & $\begin{array}{l}\text { NO: water } \\
\text { INTENSE: sugar solution } 4 \%\end{array}$ \\
\hline \multicolumn{3}{|l|}{ Texture } \\
\hline $\begin{array}{l}\text { Homogeneous texture } \\
\text { in the mouth }\end{array}$ & $\begin{array}{l}\text { Absence of lumps or particles } \\
\text { perceived in the mouth }\end{array}$ & $\begin{array}{l}\text { WEAK: Renata }{ }^{\circledR} \text { homemade noodles with hard whole eggs } \\
\text { INTENSE: Santa Amália Speciali Tagliatelle }{ }^{\circledR} \text { noodles }\end{array}$ \\
\hline
\end{tabular}




\section{Statistical analysis}

All analyses were performed in triplicate. The results are presented at the mean \pm standard deviation from the mean. The results were analyzed by unilateral analysis of variance (ANOVA), and the Tukey test $(\mathrm{P}<0.05)$ was used to determine differences between means using the Assistat 7.7 software.

\section{Results and Discussions}

\section{Beet flour characterization}

Table 2 shows the chemical composition of BF and of the fresh pasta incorporated with BF.

The proximal composition of the BF obtained in the present study was comparable to that described in both the legislation and the literature for flour from other vegetable sources: (i) the moisture content of BF $(5.67 \mathrm{~g} / 100 \mathrm{~g})$ was lower than the maximum permitted content for wheat flour $(15 \% \mathrm{w} / \mathrm{w})$ (Brasil, 2005; FDA, 2020); (ii) the protein content of BF ( $9.15 \mathrm{~g} / 100 \mathrm{~g})$ was similar to that found for wheat $(\sim 9 \mathrm{~g} / 100 \mathrm{~g})$, corn (4-9 g/100 g), and yellow pea (9.9 g/100 g) (Zhao et al., 2019) flours, and higher than that reported for green banana (3.3 g/100 g) (Flores-Silva et al., 2014) and sweet potato $(2.89 \mathrm{~g} / 100 \mathrm{~g})$ (Teye et al., 2018) flours; (iii) the lipid content $(0.45 \mathrm{~g} / 100 \mathrm{~g})$ was similar to that reported for green banana $(0.5 \mathrm{~g} / 100 \mathrm{~g})$ (Flores-Silva et al., 2014), cassava flour $(0.79 \mathrm{~g} / 100 \mathrm{~g})$ (Otondi et al., 2020), and sweet potato $(0.76 \mathrm{~g} / 100 \mathrm{~g})$ (Teye et al., 2018) flours, and lower than pupunha $(7.89 \mathrm{~g} / 100 \mathrm{~g})$ and flaxseed (21.19 $\mathrm{g} / 100 \mathrm{~g}$ ) (Sakurai et al., 2020) flours; (iv) the ash content that is related to the mineral content of BF $(5.62 \mathrm{~g} / 100 \mathrm{~g})$ was higher than that found for green banana $(2.4 \mathrm{~g} / 100 \mathrm{~g})$
(Flores-Silva et al., 2014), manioc and chia (2.59 and $4.98 \%$, respectively) (Otondi et al., 2020), sweet potato (2.19 g/100 g) (Teye et al., 2018), and bean (2.06-3.65 $\mathrm{g} / 100 \mathrm{~g}$ ) (Rios et al., 2018) flours; (v) the total dietary fiber $(21.81 \mathrm{~g} / 100 \mathrm{~g})$ was higher than those reported for sweet potato $(3 \mathrm{~g} / 100 \mathrm{~g})$, avocado pear $(9.32 \mathrm{~g} / 100 \mathrm{~g})$, and turkey berry $(11.13 \mathrm{~g} / 100 \mathrm{~g})$ (Teye et al., 2018) flours; and (vi) the energy value of BF (355.73 kcal) was lower than pumpkin peel (382.54 kcal) (Staichok et al., 2016) and okara (413.92 kcal) (dos Santos et al., 2019) flours. These results demonstrate that $\mathrm{BF}$ can contribute to fresh pasta formulations due to its good characteristics nutritional, mainly due to the high value of proteins, fibers, and minerals.

Table 3 shows the technological functional properties of BF. The WAI $(4.28 \mathrm{~g} / \mathrm{g})$ of the BF was higher than the OAC $(2.23 \mathrm{~g} / \mathrm{g})$. In comparison with the beetroot waste flour, lower values of water-holding capacity $(10.17 \mathrm{~g}$ water/g flour) and oil-holding capacity (3.35 g oil/g flour) were observed (Costa et al., 2017). Furthermore, for flour from freeze-dried stems of red beet (Beta vulgaris L.), lower values in the present study were also observed in relation to WAI (7.36 to $7.98 \mathrm{~g}$ water/g), oil absorption (5.92 to $6.26 \mathrm{~g}$ oil $/ \mathrm{g}$ ), and WS index (24.2 to $35.2 \%)$ (Wasum and Gurak, 2020). Some studies have demonstrated the impact of drying methods on the production of flour, and it is considered that all flours must undergo the assessment of the best method for its production based on the purpose of its application in the food industry (Guimarães et al., 2020). Despite the higher values observed for freeze-dried BF, it is important to highlight that the choice of processes that result in greater integrity of the raw material but also have lower execution costs can result in greater applicability in the food industry and, therefore, the convective drying process has been widely studied.

Table 2. Chemical composition of beet flour (BF) and fresh paste added 0 (OBF), 5 (5BF), 10 (10BF), and 15 (15BF) percent of BF.

\begin{tabular}{lccccc} 
& BF & OBF & 5BF & 10BF & 15BF \\
\hline Moisture $(\mathrm{g} / 100 \mathrm{~g})$ & $5.67 \pm 0.04$ & $29.87 \pm 0.82^{\mathrm{a}}$ & $29.19 \pm 1.44^{\mathrm{a}}$ & $29.05 \pm 1.82^{\mathrm{a}}$ & $30.57 \pm 0.85^{\mathrm{a}}$ \\
Protein $(\mathrm{g} / 100 \mathrm{~g})$ & $9.15 \pm 0.62$ & $14.08 \pm 0.19^{\mathrm{a}}$ & $13.83 \pm 0.12^{\mathrm{a}}$ & $13.66 \pm 0.29^{\mathrm{a}}$ & $13.55 \pm 0.43^{\mathrm{a}}$ \\
Lipid $(\mathrm{g} / 100 \mathrm{~g})$ & $0.45 \pm 0.16$ & $4.36 \pm 0.04^{\mathrm{a}}$ & $2.29 \pm 0.25^{\mathrm{b}}$ & $2.44 \pm 0.27^{\mathrm{b}}$ & $2.89 \pm 0.08^{\mathrm{b}}$ \\
Ash $(\mathrm{g} / 100 \mathrm{~g})$ & $5.62 \pm 0.04$ & $1.65 \pm 0.02^{\mathrm{d}}$ & $1.86 \pm 0.05^{\mathrm{c}}$ & $1.95 \pm 0.02^{\mathrm{b}}$ & $2.16 \pm 0.01^{\mathrm{a}}$ \\
Total carbohydrate & 79.11 & 50.04 & 52.83 & 52.90 & 50.83 \\
Insoluble fiber $(\mathrm{g} / 100 \mathrm{~g})$ & $14.96 \pm 0.11$ & $0.94 \pm 0.06^{\mathrm{c}}$ & $1.89 \pm 0.53^{\mathrm{b}}$ & $2.25 \pm 0.44^{\mathrm{ab}}$ & $3.28 \pm 0.53^{\mathrm{a}}$ \\
Soluble fiber $(\mathrm{g} / 100 \mathrm{~g})$ & $9.01 \pm 0.04$ & $0.37 \pm 0.17^{\mathrm{d}}$ & $1.81 \pm 0.62^{\mathrm{c}}$ & $2.27 \pm 0.10^{\mathrm{b}}$ & $9.01 \pm 0.04^{\mathrm{a}}$ \\
Energy (kcal) & 339.07 & 290.94 & 283.63 & 283,66 & 265.51 \\
Total betalains $(\mathrm{mg} / 100 \mathrm{~g})$ & $0.86 \pm 0.02$ & $0.04 \pm 0.01^{\mathrm{a}}$ & $0.14 \pm 0.01^{\mathrm{b}}$ & $0.16 \pm 0.03^{\mathrm{c}}$ & $0.16 \pm 0.02^{\mathrm{c}}$ \\
Total phenolic compounds $(\mathrm{mg} / 100 \mathrm{~g})$ & $88.37 \pm 0.28$ & $69.15 \pm 0.27^{\mathrm{a}}$ & $69.89 \pm 0.30^{\mathrm{b}}$ & $70.48 \pm 0.17^{\mathrm{b}}$ & $70.52 \pm 0.26^{\mathrm{b}}$ \\
Antioxidant activity $(\%)$ & $32.07 \pm 0.83$ & $0.52 \pm 0.17^{\mathrm{c}}$ & $1.78 \pm 0.96^{\mathrm{b}}$ & $2.06 \pm 1.69^{\mathrm{b}}$ & $4.76 \pm 1.58^{\mathrm{a}}$ \\
\hline
\end{tabular}


Table 3. Technological functional properties of beet flour (BF).

\begin{tabular}{lr} 
Technological functional properties & \multicolumn{1}{c}{ BF } \\
\hline Water absorption index (WAI) (g water/g flour) & $4.28 \pm 1.17$ \\
Oil absorption capacity (OAC) (g oil/g flour) & $2.23 \pm 0.20$ \\
Water solubility (WS) (\%) & $67.33 \pm 2.31$ \\
Emulsifying capacity (EC) (\%) & $30.00 \pm 3.33$ \\
Emulsifying stability (\%) & $22.41 \pm 2.51$ \\
\hline
\end{tabular}

On the other hand, compared to other vegetable flours, the WAI and OAC of BF were higher than for raw bean flour (2.16 and $1.93 \mathrm{~g} / \mathrm{g}$, respectively) (Batista et al., 2010) and for vegetable flours (1.12-1.89 and 0.93-1.38 g/g, respectively) (Du et al., 2014). Meanwhile, the WS of BF (67.33\%) was two times higher than for raw and extruded bean flour (33-35\%) (Batista et al., 2010), approximately three times higher than for vegetable flours (19.4429.14\%) (Du et al., 2014), and almost seven times higher than for chia flour (9.18\%) (Otondi et al., 2020). These parameters are important to define the applicability of new dried ingredients for the food industry. WS index is a parameter that indicates if there were degradation processes suffered by fiber constituents, such as solubilization (Wasum and Gurak, 2020). In addition, high values of WAI and OAC indicate that the flour has the ability to interact with liquid substances, allowing a greater homogeneity of the mixture (dos Santos et al., 2019), favoring its use in processing the most varied food products.

Although the values of emulsifying activity and emulsion stability were lower than those reported by Du et al. (2014) for vegetable flours (61.14-88.94\% and 84.15 and $96.90 \%$, respectively), the results obtained in the present study for the emulsion property and its stability $(30.00$ and $24.41 \%$, respectively) in BF signal the possibility of its use in meat product formulations such as sausages and hams, for example.

Foam stability decreased over time (10.43, 7.64, 5.56, 1.21 , and $0 \%$ for $0,30,60,90$, and $120 \mathrm{~min}$, respectively), and up to 120 min there was no foam previously formed. The foaming properties of flours depend mainly on the ability of a molecule to form an interfacial film by protein molecules, keeping air bubbles in suspension, and reducing coalescence. The presence of other components, such as carbohydrates in the composition of the flour, also affects its foaming properties (Sreerama et al., 2012). The results of this study revealed that the components present in BF have a low capacity to form a strong film around air bubbles. Therefore, this flour has low potential for applications where these properties are desired, as in bakery products. However, this characteristic does not limit the application of this flour in other products or its use for partial replacement of wheat flour.

\section{Fresh pasta characterization}

\section{Chemical characterization}

The addition, BF in the fresh pasta formulation did not significantly affect the moisture or protein contents of the fresh pasta. The lack of difference in protein content of the fresh pasta with control formulation was due to the protein content of the $\mathrm{BF}$, which was similar to that of wheat flour (8.57-9.00 g/100 g) (Carreira et al., 2008). The lipid content decreased significantly from 4.36 to 2.29-2.89 $\mathrm{g} / 100 \mathrm{~g}$ with the addition of BF to the fresh pasta formulations. This decrease may be related to the low lipid content present in the composition of BF $(0.45$ $\mathrm{g} / 100 \mathrm{~g})$, which was even lower than that found in wheat flour (1.29 g/100 g) (Carreira et al., 2008).

The ash content in the fresh pasta increased significantly with the increase in the addition of BF. This behavior is due to the high ash content present in BF (5.62 g/100 g), which is higher than that reported for wheat flour (0.75 g/100 g) (Carreira et al., 2008). The ash content is usually associated with the presence of minerals from beet. The main minerals found in beets are iron, calcium, sodium, zinc, manganese, and potassium (Kale et al., 2018). The inclusion of BF in cookies increased the mineral content (Chauhan and Rajput, 2018; Sahni and Shere, 2016). According to Guimarães et al. (2018), human health can be improved by the consumption of these minerals; for example, potassium decreases systolic blood pressure, iron deficiency has been associated with fatigue and with an increased risk of cardiovascular/thromboembolic events, and calcium prevents osteoporosis and fractures in adulthood and old age. Furthermore, adequate quantities of sodium ensures the maintenance of normal cellular homeostasis and the regulation of hydro electrolytic balance and blood pressure (Strazzullo and Leclercq, 2014), while zinc has critical effect in homeostasis, in immune function, in oxidative stress, apoptosis, and aging, and significant disorders of great public health interest (Chasapis et al., 2011). On the other hand, manganese participates in the metabolism of amino acids, lipids, and carbohydrates, among other functions (Szentmihályi et al., 2006).

The fiber content, both soluble and insoluble, also increased significantly with the addition of BF to the fresh pasta. This increase is due to the high fiber content present in BF $(23.97 \mathrm{~g} / \mathrm{mg})$, which was higher than that found in wheat flour $(2.40 \mathrm{~g} / 100 \mathrm{~g})$ (Carreira et al., 2008). The addition of $\mathrm{BF}$ also increased the fiber content of cookies (Chauhan and Rajput, 2018; Sahni and Shere, 2016). As a result of all these changes in the macronutrients of the fresh pasta, the caloric value of the formulations also decreased with the addition of BF, indicating that the enriched pastas were less caloric. Fibers are important components of the diet that participate in the regulation 
of intestinal functions, such as transit of intestinal mass and fecal volume, which in turn prevent constipation, diseases such as diverticulitis, hyperlipidemia, hyperglycemia, and colon cancer (Zhang et al., 2018).

The concentrations of betalains and phenolic compounds increased significantly in fresh pasta formulations with the addition of BF. For betalains, the highest concentrations were observed for formulations 10BF and 15BF (both 0.16 $\mathrm{mg} / 100 \mathrm{~g})$. Betalains are important red water-soluble pigments in the human diet because they act as antioxidants, combating free radicals, and protecting against some diseases related to oxidative stress (Vasconcellos et al., 2016). Although the incorporation of BF caused an increase in phenolic content on fresh pasta, the different levels of BF added did not produce a significant increase of phenolic content after being enriched with 5\% BF. The increase in the content of betalains and phenolic compounds is probably due to the high levels of these compounds present in the BF (0.86 and $88.34 \mathrm{mg} / 100 \mathrm{~g}$, respectively) (Table 1$)$. The phenolic compounds present in $\mathrm{BF}$ is higher than that reported for wheat flour (17.7-25.7 mg GAE/100 g) (Vaher et al., 2010). The addition of BF also increased the content of phenolic compounds and betalains in beef sausage (El-Gharably and Ashoush, 2011) and in Julpyun (Ko and Jeong, 2017).

The addition of BF increased the antioxidant capacity of the fresh pasta. Fresh pasta formulations supplemented with BF showed higher antioxidant activity (1.78-4.76\%), compared to $\mathrm{OBF}(0.52 \%)$. Similar results have already been observed in other studies and attributed to the high content of phenolic compounds and betalains present in BF (El-Gharably and Ashoush, 2011; Jeong et al., 2014; Ko and Jeong, 2017).

According to Pasqualone et al. (2016), the supplementation of fresh pasta can be realized to improve its nutritional value and its antioxidant activity. The use of ingredients with nutritional properties is a field that has been explored by other researchers (De Santis et al., 2020; Fradinho et al., 2020; Kowalczewski et al., 2019).

The results in the present study indicated that the addition of BF for partial replacement of wheat flour by BF in the formulation of ready-made pasta can improve the nutritional and functional values of these pasta, reducing the lipid content and increasing the concentration of total minerals, soluble and insoluble fibers, phenolic compounds, betalains, and antioxidant activity.

\section{Technological characterization}

Table 4 presents the results of the technological parameters of fresh pasta with partial replacement of wheat flour with BF. Baking quality parameters are widely used empirical determinants to provide important indications about the quality of the pasta during baking. The cooking time of fresh pasta showed no significant difference between the formulations studied, meaning BF did not interfere with the cooking time of the pasta. In the present study, the cooking time was shorter than cooking times previously observed for pasta with pigeon pea flour (Casagrandi et al., 1999), S. platensis (Lemes et al., 2012), and fresh multigrain pasta (rice, oat, and soy) (Oliveira Filho et al., 2021).

The statistical analysis of the averages used the Tukey test, whereas the same letters on the columns represent no significant differences at the significance level of $5 \%$.

The substitution of wheat flour for BF did not significantly change the cooking time (approximately $5 \mathrm{~min}$ ) $(\mathrm{P}<0.05)$, the displaced volume $(14.5-15.0 \%)$, or the loss of solids (2.57-3.25) in the enriched formulations. There was lower water loss in fresh pasta with BF when compared to fresh pasta with S. platensis (Lemes et al., 2012). Except for the $15 \mathrm{BF}$ formulation, the volume displacement was lower than presented by Lemes et al. (2012) for fresh pasta with S. platensis and higher than those reported by Oliveira Filho et al. (2021) due to the presence of a matrix composed of rice, oat, and soy that participate more efficiently in the structuring of the fresh pasta.

On the other hand, cooking loss represents the quality of solids lost in water during the cooking process of the pasta. The lower the loss of organic matter during this process, the better the product quality (De Santis et al., 2020), and this value should not exceed $10 \mathrm{~g}$ per $100 \mathrm{~g}$ of dry pasta (Wu et al., 1987). All formulations developed

Table 4. Technological properties of fresh pasta developed and enriched with beet flour.

\begin{tabular}{lcccc} 
Properties & OBF & $5 \mathrm{BF}$ & $10 \mathrm{BF}$ & $15 \mathrm{BF}$ \\
\hline Cooking time (min) & $5.3 \pm 0.6^{\mathrm{a}}$ & $5.0 \pm 0.0^{\mathrm{a}}$ & $5.0 \pm 0.0^{\mathrm{a}}$ & $5.0 \pm 0.0^{\mathrm{a}}$ \\
Water retention capacity (\%) & $156.59 \pm 28.71^{\mathrm{ab}}$ & $187.36 \pm 23.09^{\mathrm{a}}$ & $117.97 \pm 15.04^{\mathrm{b}}$ & $167.71 \pm 8.04^{\mathrm{ab}}$ \\
Volume displacement (\%) & $14.50 \pm 0.50^{\mathrm{a}}$ & $14.50 \pm 0.50^{\mathrm{a}}$ & $14.66 \pm 0.58^{\mathrm{a}}$ & $15.00 \pm 0.0^{\mathrm{a}}$ \\
Loss of solids (\%) & $2.57 \pm 0.82^{\mathrm{a}}$ & $2.63 \pm 0.11^{\mathrm{a}}$ & $3.12 \pm 0.07^{\mathrm{a}}$ & $3.25 \pm 0.60^{\mathrm{a}}$ \\
Water absorption (\%) & $61.30 \pm 6.67^{\mathrm{a}}$ & $52.94 \pm 6.77^{\mathrm{ab}}$ & $52.73 \pm 8.27^{\mathrm{ab}}$ & $32.13 \pm 13.81^{\mathrm{b}}$ \\
\hline
\end{tabular}


in this study showed values below 3.3\%, which was lower compared to fresh pasta with $\beta$-glucan $12.1-14.1 \mathrm{~g} / 100 \mathrm{~g}$ (De Santis et al., 2020) and similar to that observed in fresh pasta with the addition of brown flour 2.75-3.75 g/100g (Littardi et al., 2020). Water absorption decreased when wheat flour was replaced with BF in fresh pasta. The 15BF formulation showed half of the water absorption compared to the control formulation. This characteristic may be due to the solubilization of the starch during gelatinization. Formulations with a higher BF content showed a reduction in the wheat flour content and consequently in the starch content and gelatinization.

\section{Sensorial profile}

Table 5 shows the results of the sensory analysis of fresh pasta with the addition of BF. The formulations differed significantly in the attributes of red color, homogeneous appearance, beet aroma, beet flavor, sweet flavor, and homogeneous texture in the mouth. Formulations with $\mathrm{BF}$ addition showed the highest intensity for these attributes, and the highest values were observed for formulations with the highest concentrations of BF (10BF and 15BF). In particular, evaluations of taste, texture, and appearance characteristics of fresh pasta suggested that the addition of BF increases the sensory complexity of the product, as confirmed by the higher value expressed by the judges for formulations with higher concentrations of BF (Table 5).

Similar behavior was reported by El-Gharably and Ashoush (2011) for sausages with BF added. The formulations that contained 1 and $3 \%$ of BF demonstrated the highest sensory scores among the samples of beef sausage. According to Oliviero and Fogliano (2016), the incorporation of vegetables can lead to changes in the sensory attributes of fresh pasta. Therefore, for this

Table 5. Sensorial profile of fresh pasta developed and enriched with beet flour. ${ }^{1}$

\begin{tabular}{lcccc} 
Attributes & $0 \mathrm{BF}$ & $5 \mathrm{BF}$ & $10 \mathrm{BF}$ & $15 \mathrm{BF}$ \\
\hline Red color & $10^{\mathrm{a}}$ & $20^{\mathrm{ac}}$ & $31^{\mathrm{bc}}$ & $39^{\mathrm{b}}$ \\
Homogeneous appearance & $13^{\mathrm{a}}$ & $22^{\mathrm{acd}}$ & $29^{\mathrm{bcd}}$ & $33^{\mathrm{bd}}$ \\
Egg aroma & $20^{\mathrm{a}}$ & $23^{\mathrm{a}}$ & $28^{\mathrm{a}}$ & $26^{\mathrm{a}}$ \\
Beet aroma & $11^{\mathrm{a}}$ & $23^{\mathrm{b}}$ & $29^{\mathrm{b}}$ & $37^{\mathrm{b}}$ \\
Beet flavor & $10^{\mathrm{a}}$ & $21^{\mathrm{acd}}$ & $31^{\mathrm{bc}}$ & $38^{\mathrm{bd}}$ \\
Sweetness flavor & $13^{\mathrm{a}}$ & $22^{\mathrm{ac}}$ & $28^{\mathrm{bc}}$ & $37^{\mathrm{bd}}$ \\
$\begin{array}{l}\text { Homogeneous texture in } \\
\text { the mouth }\end{array}$ & $17^{\mathrm{a}}$ & $21^{\mathrm{ac}}$ & $29^{\mathrm{bc}}$ & $33^{\mathrm{bd}}$ \\
& & & &
\end{tabular}

Sum of RDA values for 12 judges. ${ }^{1}$ Different letters on the same line indicate a significant difference $(P<0.05)$, compared with Newell and MacFarlane's (1987) table. Critical value: 12 (4 samples and 12 judges). strategy to be successful, it is necessary that during processing conditions are optimized so that the final product has the desired nutritional and sensory characteristics.

\section{Conclusions}

In general, the results of the present study showed that the addition of BF can be a promising strategy in the development of new formulations of fresh pasta. To our knowledge, the results of the present study indicate for the first time the evaluation of the physicochemical modifications produced in fresh pasta formulations by the addition of BF. The partial replacement of wheat flour with $\mathrm{BF}$ in the formulation of ready-made pasta improved the nutritional and functional profile of fresh pasta, reducing the lipid content and increasing the concentration of total minerals, soluble and insoluble fibers, phenolic compounds, betalain content, and antioxidant activity. Regarding the sensory profile, the pastas formulated with the highest concentrations of $\mathrm{BF}$ registered the highest scores for the sensory attributes. However, further studies would be needed to assess the changes in terms of texture and bioactive properties of the pasta after cooking, and also to investigate the use of BF in the formulation of gluten-free pasta.

\section{Author Contributions}

Josemar Gonçalves de Oliveira Filho, Ailton Cesar Lemes, and Eliane Dalva Godoy Danesi were involved in the original draft preparation. Ailton Cesar Lemes, Ricardo Pereira Cruz Filho, Rafaiane Macedo Guimarães, Kamylla Lina Oliveira, Gabriela Silva Santana, and Eliane Dalva Godoy Danesi were concerned with methodology and investigation. Mariana Buranelo Egea was involved in conceptualization, funding acquisition, supervision, writing, reviewing, and editing

\section{Acknowledgement}

The authors acknowledge the financial support of CNPq, FAPEG, CAPES, and IF Goiano.

\section{References}

AACC, 2000. Approved methods of the AACC. AACC, St. Paul, MN. AOAC, 2000. Official methods of analysis. Association of Official Analytical Chemists,Washington: Official methods of Analysis. AOAC. (2007). Association of official analytical chemists. Washington: Official methods of Analysis.

Analysis.Batista, K.A., Prudêncio, S.H. and Fernandes, K.F., 2010. Changes in the biochemical and functional properties of the 
extruded hard-to-cook cowpea (Vigna unguiculata L. Walp). International Journal of Food Science \& Technology 45: 794799. http://dx.doi.org/10.1111/j.1365-2621.2010.02200.x

Benzie, I.F. and Strain, J., 1999. Ferric reducing/antioxidant power assay: direct measure of total antioxidant activity of biological fluids and modified version for simultaneous measurement of total antioxidant power and ascorbic acid concentration. Methods in Enzymology 299: 15-27. http://dx.doi.org/10.1016/ S0076-6879(99)99005-5

Brand-Williams, W., Cuvelier, M.-E. and Berset, C., 1995. Use of a free radical method to evaluate antioxidant activity. LWT-Food Science and Technology 28: 25-30. http://dx.doi.org/10.1016/ S0023-6438(95)80008-5

Brasil, 2005. Technical regulation of wheat flour identity and quality, In 8/2005. Ministry of Agriculture, Livestock and Food Supply (MAPA), Brasília, BR.

Cappa, C. and Alamprese, C., 2017. Brewer's spent grain valorization in fiber-enriched fresh egg pasta production: modelling and optimization study. LWT-Food Science and Technology 82: 464-470. http://dx.doi.org/10.1016/j.lwt.2017.04.068

Carreira, R.L., Silva, M.R., Starling, A.L.P., Aguiar, M.J., Januario, J.N. and Silvestre, M.P., 2008. Association of two enzymes for obtaining low phenylalanine protein hydrolysates from wheat flour. International Journal of Food Engineering 4: 1-9. http://dx.doi. org/10.2202/1556-3758.1544

Casagrandi, D.A., Canniatti-Brazaca, S.G., Salgado, J.M., Pizzinato, A. and Novaes, N.J., 1999. Technological, nutritional and sensorial analysis of macaroni elaborated with wheat and pigeon pea flours. Revista de Nutrição 12: 137-143. http://dx. doi.org/10.1590/S1415-52731999000200003

Chang, Y.K. and Martínez Flores, H.E., 2004. Quality of fresh pastas obtained from blends of durum wheat semolina (T. durum L.) and wheat flour (T. aestivum L.). Food Science and Technology 24: 487-493. https://dx.doi.org/10.1590/S0101-20612004000400002.

Chasapis, C., Loutsidou, A., Spiliopoulou, C. and Stefanidou, M., 2011. Zinc and human health: an update. Archives of Toxicology 86: 521-534. http://dx.doi.org/10.1007/s00204-011-0775-1

Chauhan, S. and Rajput, H., 2018. Production of gluten free and high fiber cookies using beet root waste powder and wheat flour husk. The Pharma Innovation Journal 7: 556.

Clímaco, G.N., Sousa, M.L., Seccadio, L.L. and de Freitas, A.C., 2020. Physical-chemical and sensory evaluation of cookie made with potato (Solanum tuberosum L.) and beet (Beta vulgaris L.) Mixed flour. Research, Society and Development 9: e943975204. http://dx.doi.org/10.33448/rsd-v9i7.5204

Coffmann, C. and Garciaj, V., 1977. Functional properties and amino acid content of a protein isolate from mung bean flour. International Journal of Food Science \& Technology 12: 473484. http://dx.doi.org/10.1111/j.1365-2621.1977.tb00132.x

Costa, A.P.D., Hermes, V.S., Rios, A.D.O. and Flôres, S.H., 2017. Minimally processed beetroot waste as an alternative source to obtain functional ingredients. Journal of Food Science and Technology 54: 2050-2058. http://dx.doi.org/10.1007/ s13197-017-2642-4

De Santis, D., Moresi, M. and Cimini, A., 2020. Effect of $\beta$-glucan enrichment on the sensory properties of fresh egg white pasta.
LWT-Food Science and Technology 130:109654. http://dx.doi. org/10.1016/j.lwt.2020.109654

dos Santos, D.C., de Oliveira Filho, J.G., de Santana Silva, J., de Sousa, M.F., da Silva Vilela, M., et al. 2019. Okara flour: its physicochemical, microscopical and functional properties. Nutrition \& Food Science 49:1252-1264. http://dx.doi.org/10.1108/NFS-11-2018-0317

Du, S.-K., Jiang, H., Yu, X. and Jane, J.-L., 2014. Physicochemical and functional properties of whole legume flour. LWT-Food Science and Technology 55: 308-313. http://dx.doi.org/10.1016/j. lwt.2013.06.001

El-Gharably, A.M. and Ashoush, I., 2011. Utilization impact of adding pomegranate rind powder and red beet powder as natural antioxidant on quality characteristics of beef sausage. World Journal of Dairy \& Food Sciences 6: 86-97.

FDA, 2020. Food and Drug Administration Department of Health and Human Services. PART 137 - Cereal flours and related products: Subpart B - Requirements for specific standardized cereal flours and related products. In: Subchapter B - Food for Human Consumption. Revised as of April 1, 2020. Code of Federal Regulations Title 21, 2: 21CFR137.170

Flores-Silva, P.C., Berrios, J.D.J., Pan, J., Osorio-Díaz, P. and BelloPérez, L.A., 2014. Gluten-free spaghetti made with chickpea, unripe plantain and maize flours: functional and chemical properties and starch digestibility. International Journal of Food Science \& Technology 49: 1985-1991. http://dx.doi.org/10.1111/ ijfs. 12529

Fradinho, P., Niccolai, A., Soares, R., Rodolfi, L., Biondi, N., Tredici, M.R., et al. 2020. Effect of Arthrospira platensis (spirulina) incorporation on the rheological and bioactive properties of gluten-free fresh pasta. Algal Research 45: 101743. http://dx. doi.org/10.1016/j.algal.2019.101743

Giménez, M.A., González, R., Wagner, J., Torres, R., Lobo, M.O. and Samman, N.C., 2013. Effect of extrusion conditions on physicochemical and sensorial properties of corn-broad beans (Vicia faba) spaghetti type pasta. Food Chemistry 136: 538-545. http://dx.doi.org/10.1016/j.foodchem.2012.08.068

Guimarães, R.M., Ida, E.I., Falcão, H.G., de Rezende, T.A.M., de Santana Silva, J., Alves, C.C.F., et al. 2020. Evaluating technological quality of okara flours obtained by different drying processes. LWT-Food Science and Technology 123: 109062. http://dx.doi. org/10.1016/j.lwt.2020.109062

Guimarães, R.M., Silva, T.E., Lemes, A.C., Boldrin, M.C.F., da Silva, M.A.P., Silva, F.G. and Egea, M.B., 2018. Okara: a soybean by-product as an alternative to enrich vegetable paste. LWT-Food Science and Technology 92: 593-599. http://dx.doi. org/10.1016/j.lwt.2018.02.058

Jeong, Y.-Z., Jin, S.-Y. and Han, Y.-S., 2014. Functional and quality characteristics of glutinous barley Jeung-pyun added with beet (Beta vulgaris L.) powder. The Korean Journal of Food And Nutrition 27: 1-9. http://dx.doi.org/10.9799/ksfan.2014.27.1.001

Joo, N.-M. and Kim, S.-J., 2010. Optimizing production conditions of germinated brown rice cookie prepared with beet powder. Journal of the Korean Dietetic Association 16: 332-340.

Kale, R., Sawate, A., Kshirsagar, R., Patil, B. and Mane, R., 2018. Studies on evaluation of physical and chemical composition of beetroot (Beta vulgaris L.). International Journal of Clinical 
Sciences 6: 2977-2979. Available at: https://www.chemijournal. com/archives/2018/vol6issue2/PartAP/6-2-300-442.pdf

Ko, S.-H. and Jeong, H.-C., 2017. Quality characteristics of Julpyun with added beet powder. Journal of the Korean Society of Food Culture 32: 576-582. https://dx.doi.org/10.7318/ KJFC/2017.32.6.576

Kowalczewski, P.Ł., Pauter, P., Smarzyński, K., Różańska, M.B., Jeżowski, P., Dwiecki, K. and Mildner-Szkudlarz, S., 2019. Thermal processing of pasta enriched with black locust flowers affect quality, phenolics, and antioxidant activity. Journal of Food Processing and Preservation 43: e14106. http://dx.doi. org/10.1111/jfpp.14106

Lee, C.H., Cho, J.K., Lee, S.J., Koh, W., Park, W. and Kim, C.H., 2002. Enhancing $\beta$-carotene content in Asian noodles by adding pumpkin powder. Cereal Chemistry 79: 593-595. http://dx.doi. org/10.1094/CCHEM.2002.79.4.593

Lee, E.-J. and Ju, H.-W., 2016. Quality characteristics of bread added with beet powder. Journal of the East Asian Society of Dietary Life 26: 55-62. http://dx.doi.org/10.17495/easdl.2016.2.26.1.55

Lemes, A.C., Takeuchi, K.P., Carvalho, J.C.M.D. and Danesi, E.D.G., 2012. Fresh pasta production enriched with Spirulina platensis biomass. Brazilian Archives of Biology and Technology 55: 741750. http://dx.doi.org/10.1590/S1516-89132012000500014

Li, W., Hydamaka, A.W., Lowry, L. and Beta, T., 2009. Comparison of antioxidant capacity and phenolic compounds of berries, chokecherry and seabuckthorn. Central European Journal of Biology 4: 499-506. http://dx.doi.org/10.2478/s11535-009-0041-1

Littardi, P., Paciulli, M., Carini, E., Rinaldi, M., Rodolfi, M. and Chiavaro, E., 2020. Quality evaluation of chestnut flour addition on fresh pasta. LWT-Food Science and Technology 126:109303. http://dx.doi.org/10.1016/j.lwt.2020.109303

Miller, N.J., Rice-Evans, C., Davies, M.J., Gopinathan, V. and Milner, A., 1993. A novel method for measuring antioxidant capacity and its application to monitoring the antioxidant status in premature neonates. Clinical Science 84: 407-412. http://dx. doi.org/10.1042/cs0840407

Newell, G. and MacFarlane, J., 1987. Expanded tables for multiple comparison procedures in the analysis of ranked data. Journal of Food Science 52: 1721-1725. http://dx.doi. org/10.1111/j.1365-2621.1987.tb05913.x

Nishida, C., Uauy, R., Kumanyika, S. and Shetty, P., 2004. The joint WHO/FAO expert consultation on diet, nutrition and the prevention of chronic diseases: process, product and policy implications. Public Health Nutrition 7: 245-250. http://dx.doi. org/10.1079/PHN2003592

Okezie, B.O. and Bello, A., 1988. Physicochemical and functional properties of winged bean flour and isolate compared with soy isolate. Journal of Food Science 53: 450-454. http://dx.doi. org/10.1111/j.1365-2621.1988.tb07728.x

Oliveira Filho, J.G., dos Santos, D.C., Silva, M.S., Carvalho, T.D.P., Lemes, A.C. and Egea, M.B., 2021. Physicochemical, technological, and sensory characteristics of fresh multigrain pasta: a multicomponent mixture experiments approach. Journal of Food Processing and Preservation n/a: e15393. http://dx.doi.org/10.1111/jfpp.15393

Oliviero, T. and Fogliano, V., 2016. Food design strategies to increase vegetable intake: the case of vegetable enriched pasta.
Trends in Food Science \& Technology 51: 58-64. http://dx.doi. org/10.1016/j.tifs.2016.03.008

Otondi, E., Nduko, J.M. and Omwamba, M., 2020. Physico-chemical properties of extruded cassava-chia seed instant flour. Journal of Agriculture and Food Research 2:100058. http://dx.doi. org/10.1016/j.jafr.2020.100058

Pandita, D., Pandita, A., Pamuru, R.R. and Nayik, G.A., 2020. Beetroot. In: Nayik, G.A. and Gull, A. (eds.), Antioxidants in vegetables and nuts - properties and health benefits. Springer Singapore, Singapore, pp. 45-74. http://dx.doi. org/10.1007/978-981-15-7470-2_3

Pasqualone, A., Gambacorta, G., Summo, C., Caponio, F., Di Miceli, G., Flagella, Z., et al. 2016. Functional, textural and sensory properties of dry pasta supplemented with lyophilized tomato matrix or with durum wheat bran extracts produced by supercritical carbon dioxide or ultrasound. Food Chemistry 213: 545-553. http://dx.doi.org/10.1016/j.foodchem.2016.07.006

Rios, M.J.B.L., Damasceno-Silva, K.J., Moreira-Araújo, R.S.d.R., Figueiredo, E.A.T.d., Rocha, M.D.M. and Hashimoto, J.M., 2018. Chemical, gand technological characteristics of whole flours from commercial cultivars of cowpea. Revista Caatinga 31: 217224. http://dx.doi.org/10.1590/1983-21252018v31n125rc

Rufino, M.D.S.M., Alves, R.E., de Brito, E.S., Pérez-Jiménez, J., Saura-Calixto, F. and Mancini-Filho, J., 2010. Bioactive compounds and antioxidant capacities of 18 non-traditional tropical fruits from Brazil. Food Chemistry 121: 996-1002. http://dx.doi. org/10.1016/j.foodchem.2010.01.037

Sahni, P. and Shere, D., 2016. Physico-chemical and sensory characteristics of beet root pomace powder incorporated fibre rich cookies. International Journal of Food and Fermentation Technology 6: 309-315. http://dx.doi. org/10.5958/2277-9396.2016.00055.6

Sakurai, Y.C.N., Rodrigues, A.M.D.C., Pires, M.B. and Silva, L.H.M.D., 2020. Quality of pasta made of cassava, peach palm and golden linseed flours. Food Science and Technology 40: 228-234. http://dx.doi.org/10.1590/fst.09119

Seo, E.-O. and Ko, S.-H., 2014. Quality characteristics of muffins containing beet powder. Culinary Science and Hospitality Research 20: 27-37. http://dx.doi.org/10.20878/cshr.2014.20.1.003

Singleton, V.L. and Rossi, J.A., 1965. Colorimetry of total phenolics with phosphomolybdic-phosphotungstic acid reagents. American Journal of Enology and Viticulture 16: 144-158.

Sissons, M.J., Soh, H.N. and Turner, M.A., 2007. Role of gluten and its components in influencing durum wheat dough properties and spaghetti cooking quality. Journal of the Science of Food and Agriculture 87: 1874-1885. https://dx.doi.org/10.1002/jsfa.2915

Sreerama, Y.N., Sashikala, V.B., Pratape, V.M. and Singh, V., 2012. Nutrients and antinutrients in cowpea and horse gram flours in comparison to chickpea flour: evaluation of their flour functionality. Food Chemistry 131: 462-468. http://dx.doi.org/10.1016/j. foodchem.2011.09.008

Staichok, A.C.B., Mendonça, K.R.B., dos Santos, P.G.A., Garcia, L.G.C. and Damiani, C., 2016. Pumpkin peel flour (Cucurbita máxima L.)-characterization and techological applicability. Journal of Food and Nutrition Research 4: 327333. http://dx.doi.org/10.12691/jfnr-4-5-9 
Strazzullo, P. and Leclercq, C., 2014. Sodium. Advances in Nutrition (Bethesda, Md.) 5: 188-190. http://dx.doi.org/10.3945/an.113. 005215

Szentmihályi, K., Vinkler, P., Fodor, J., Balla, J. and Lakatos, B., 2006. The role of manganese in the human organism. Orvosi Hetilap 147: 2027-2030. PMID: 17165602

Tang, C., Norziah, M. and Norziah, M., 2007. Stability of betacyanin pigments from red purple pitaya fruit (Hylocereus polyrhizus): influence of $\mathrm{pH}$, temperature, metal ions and ascorbic acid. Indonesian Journal of Chemistry 7: 327-331. http://dx.doi. org/10.22146/ijc.21678

Tazrart, K., Zaidi, F., Salvador, A. and Haros, C.M., 2019. Effect of broad bean (Vicia faba) addition on starch properties and texture of dry and fresh pasta. Food Chemistry 278: 476-481. http://dx.doi.org/10.1016/j.foodchem.2018.11.036

Teye, E., Agbemafle, R. and Lamptey, F.P., 2018. Development and examination of sweet potato flour fortified with indigenous underutilized seasonal vegetables. Beverages 4: 5. http://dx.doi. org/10.3390/beverages4010005

Vaher, M., Matso, K., Levandi, T., Helmja, K. and Kaljurand, M., 2010. Phenolic compounds and the antioxidant activity of the bran, flour and whole grain of different wheat varieties. Procedia Chemistry 2: 76-82. http://dx.doi.org/10.1016/j. proche.2009.12.013

Vasconcellos, J., Conte-Junior, C., Silva, D., Pierucci, A.P., Paschoalin, V. and Alvares, T.S., 2016. Comparison of total antioxidant potential, and total phenolic, nitrate, sugar, and organic acid contents in beetroot juice, chips, powder, and cooked beetroot. Food Science and Biotechnology 25: 79-84. http://dx.doi.org/10.1007/s10068-016-0011-0

Wasum, M.M. and Gurak, P.D., 2020. Physical-chemical characterization of flour from freeze-dried beet stems (Beta vulgaris L.). In: Silva, F.R. (ed.), Equidade e sustentabilidade no campo da segurança alimentar global. Atena, Ponta Grossa, PR, pp. 36-45. http://dx.doi.org/10.22533/at.ed.2472024045

Wu, Y., Youngs, V., Warner, K. and Bookwalter, G., 1987. Evaluation of spaghetti supplemented with corn distillers' dried grains. Cereal Chemistry 64: 434-436.

Yasumatsu, K., Sawada, K., Moritaka, S., Misaki, M., Toda, J., Wada, T. and Ishii, K., 1972. Whipping and emulsifying properties of soybean products. Agricultural and Biological Chemistry 36: 719-727. http://dx.doi.org/10.1080/00021369.1972.10860321

Zhang, H., Wang, H., Cao, X. and Wang, J., 2018. Preparation and modification of high dietary fiber flour: a review. Food Research International 113: 24-35. http://dx.doi.org/10.1016/j. foodres.2018.06.068

Zhao, J., Liu, X., Bai, X. and Wang, F., 2019. Production of biscuits by substitution with different ratios of yellow pea flour. Grain \& Oil Science and Technology 2: 91-96. http://dx.doi.org/10.1016/j. gaost.2019.09.004 